\title{
Palynomorphological Data of Some Species of the Genus Achillea
}

\author{
Anxhela Dauti ${ }^{1}$ \\ Gëzim Kapidani2 \\ Blerina Pupuleku \\ Nikoleta Kallajxhiu ${ }^{1}$ \\ Admir Jançe ${ }^{3}$ \\ Silvana Turku ${ }^{1}$ \\ ${ }^{1}$ Department of Biology, Faculty of Natyral Sciences, University "A. Xhuvani", Elbasan, Albania \\ 2Department of Biology, Faculty of Natyral Sciences, University of Tirana, Tirana, Albania \\ ${ }^{3}$ Albanian University, Tirana, Albania \\ Email: anxhela.dauti@uniel.edu.al
}

Doi:10.5901/ajis.2016.v5n3s1p74

\section{Abstract}

The article includes the palynomorphological study of some species of the genus Achillea in Albania. In this article submitted comparative features of the species: Achillea abrotanoides, Achillea ageratifolia, Achillea clavennae, Achillea chrysocoma dhe Achillea millefolium. The material for the study was obtained in National Herbarium in Tirana. For the study of palynomorphological features are analyzed 31 pollen grains from each species. The treatment of material is made with acetolysis method and basic fuchsine. The fixing of pollen grains is made with glycerin gelatin. The study and photos of pollen grains are realized with light microscope with 1000x power. Between the plant species included in the study are differences and similarities regarding the palynological features such as: dimension of pollen grain, thickness of exine, length of spines, width of spines. The pollen grains of plants above are tricolporate. The shape of pollen grains by the outline appears spheroidal or prolate spheroidal. The exine appears thick and has two-layers. The sculpture of exine is echinate.

Keywords: Achillea, palynomorphological, pollen grain, exine, spines

\section{Introduction}

The genus Achillea is part of the family Asteraceae (Compositae), the largest family of vascular plants. This genus is represented by about 140 species distributed in Europe, in warmer areas of Asia and some in North America(Nemeth and Bernath, 2008; Saeidnia et al., 2011). In Flora of Albania the genus Achillea represented by 18 species (Anonymous, 1988-2000). The name of Achillea is referred to the Achilles, who in the Trojan war has used these plants to cure the wounds of his soldiers (Saeidnia et al., 2011).

The species of Achillea has been used since ancient times as medicinal plants for the treatment of many diseases as: anemia, diseases of the stomach, loss of appetite, menstrual irregularities etc. (Nemeth and Bernath, 2008; Saeidnia et al., 2011 ; Anonymous, 1988-2000). Other studies have shown for antioxidant and antibacterial action that have oily essences of species of the genus Achillea (Vitalini et al., 2016; Issabeagloo1 et al., 2012; Alfatemi, et al., 2015; Mazandarani et al., 2013; Benedec et al., 2013).

The morphological description of the pollen grains of several species of the genus Achillea is made by Wodehouse, 1935 and then by other authors(Erdtman, 1943; Meo \& Khan, 2003; Akyalcin et al., 2010; Punt and Hoen, 2009; Kapidani, 1996; etc.).

In this paper presented morphological study of pollen grains of species: Achillea abrotanoides, Achillea ageratifolia, Achillea clavennae, Achillea chrysocoma and also compared with the palynomorphological data of Achillea millefolium taken from literature (Kapidani, 1996). The palynomorphological data of plant species: Achillea abrotanoides, Achillea ageratifolia, Achillea clavennae, Achillea chrysocoma presented for the first time in the palynological literature of our country. 


\section{Material and Methods}

The material for the study was obtained in National Herbarium in Tirana. To achieve the study of pollens' morphological characteristics we have used three analytical methods.

- Acetolysis of Erdtman method (Erdtman, 1956)

- Acetolysis of Avetisjan method (Avetisjan, 1950)

- Basic fuchsine method of Smoljaninova \&Gollubkova, (1953)

The fixing of pollen grains is made with glycerin gelatin prepared according to Kisser method (Sllatkov, 1967) The palynomorphological dates in this study regard the material acetolysed. In order to accomplish the quantitative analysis of palynomorphological features, 31 pollen grains are taken in consideration. There were prepared 3-5 microscope slide for each plant bydifferent methods and they were studied by the Digital Microscope/Camera Software, Motic Images Plus 2.0 ML, B1Series. (This microscop saves images in JPG, BMP, MIG and TIFF and process the image with a variety of filters). The microscopic photos of pollen grains of the plant studied presented in polar and equatorial view with magnification 1000X, taken by DAUTI Anxhela.The terminology is based on that recommended previously Erdtman (1952), Punt et al. (,1994) and Kapidani, ( 2005).

\section{Results and Discussion}

Representatives of the genus Achillea are perennial plant, with white flowers, yellow, rarely pink. They grow in rocky areas, alpine meadows, near roads etc. ( Anonymous, 1988-2000; Demiri, 1983)

The pollen grains representatives of this genus are monad, tricolporate, with spheroidal to prolate spheroidal outline. Pores of pollen grains have circular outline. The pore's diameter varies from $3-5 \mu \mathrm{m}$. Mesocolpium varies from $14.65-20.2 \mu \mathrm{m}$. Exine is thick and two-layer with echinate sculpture. The spines are conical and their length varies from 2 - $4 \mu \mathrm{m}$, while their width varies from 2 - $6 \mu \mathrm{m}$. The distance between spinules varies from 2- $4 \mu \mathrm{m}$. Thickness of exine varies from $3-6 \mu \mathrm{m}$. Ectexine is thicker than endexine. In ectexine is observed the presence of columellae and the tectum with thickness about $1 \mu \mathrm{m}$. Polar axis of pollen grains varies from 20.6 - $35.5 \mu \mathrm{m}$, while equatorial diameter varies from 20.6 - $35.2 \mu \mathrm{m}$. ( fig.1,2,3,4,5).

The palynological features of each representative included in the study are expressed in Table 1,2 and shown through microscopic photos.

3.1 Achillea abrotanoides (Vis.) Vis. Fl. Dalm. 2:81 (1847)
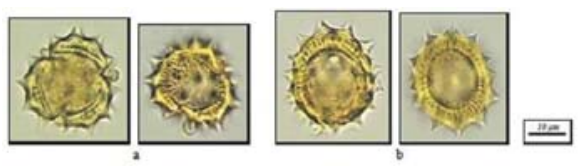

Figure 1. Pollen grains Achillea abrotanoides; a. polar view; b. equatorial view. (1000 X)

3.2 Achillea ageratifolia (Sibth. et Sm.) Boiss., Fl. Or. 3:275 (1875).

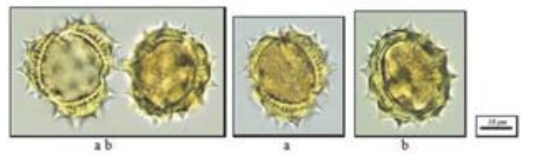

Figure 2. Pollen grains Achillea ageratifolia: a. polar view; b. equatorial view. (1000 X)

3.3 Achillea clavennae L., Sp. PI. 898 (1753).
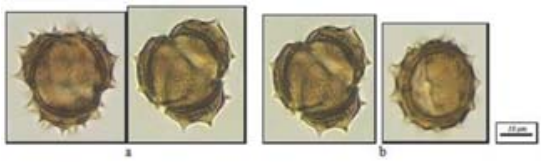

Figure 3. Pollen grains Achillea clavennae: a. polar view; b. equatorial view. (1000 X) 
3.4 Achillea chrysocoma Friv., Flora (Regensb.) 18:366 (1835).
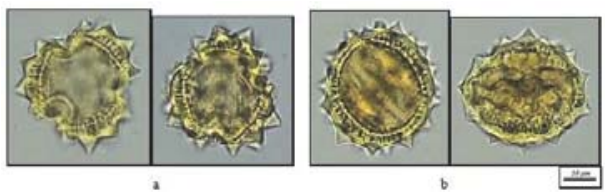

Figure 4. Pollen grains Achillea chrysocoma: a. polar view; b. equatorial view. (1000 X)

3.5 Achillea millefolium L. , Sp. PI. 899 (1753)

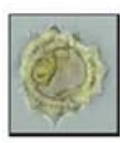

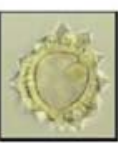

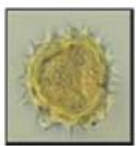

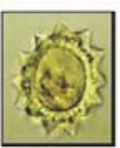

b

Figure 5. Pollen grains Achillea millefolium a. polar view; b. equatorial view. (1000 X)

Table 1. Dimensions of pollen grains of the plant species Achillea

\begin{tabular}{|c|c|c|c|c|c|}
\hline \multicolumn{6}{|c|}{ The palynological features Achillea abrotanoides Achillea ageratifolia Achillea clavennae Achillea chrysocoma Achillea millefolium } \\
\hline Polar axis $(\mathrm{P}) \mu \mathrm{m}$ & $\begin{array}{c}24-30 \\
(26)\end{array}$ & $\begin{array}{c}29-34 \\
(31.2)\end{array}$ & $\begin{array}{c}30-33 \\
(30.8)\end{array}$ & $\begin{array}{c}32-38 \\
(35.5)\end{array}$ & $\begin{array}{c}20-21.3 \\
(20.6)\end{array}$ \\
\hline Equatorial diameter $(\mathrm{E}) \boldsymbol{\mu m}$ & $\begin{array}{c}24-28 \\
(26.4)\end{array}$ & $\begin{array}{c}28-32 \\
(30)\end{array}$ & $\begin{array}{c}28-32 \\
(29.9)\end{array}$ & $\begin{array}{l}32-37 \\
(35.2)\end{array}$ & $\begin{array}{c}20-21.3 \\
(20.6)\end{array}$ \\
\hline
\end{tabular}

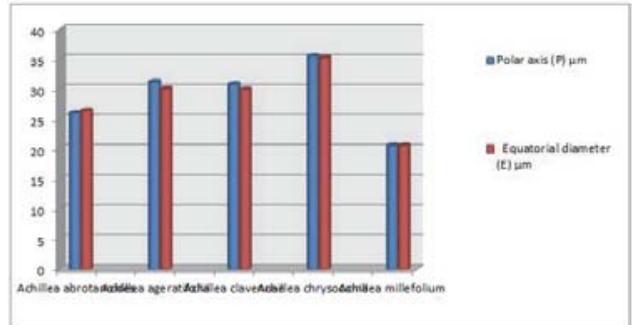

Figure 6. Chart of average dimensions of pollen grains of species Achillea

Based on the data of the table.1 and the fig. 6 observed changes in the size of pollen grains of species Achillea, take in the study. The pollen grains of Achillea chrysocoma are greater than those of Achillea abrotanoides, Achillea ageratifolia, Achillea clavennae, Achillea millefolium, while pollen grains of Achillea millefolium are smaller than other species take in the study.

Table 2. Comparative table of palynomorphologic features of genus Achillea

\begin{tabular}{|c|c|c|c|c|c|}
\hline \multicolumn{6}{|c|}{ The palynological features Achillea abrotanoides Achillea ageratifolia Achillea clavennae Achillea chrysocoma Achillea millefolium } \\
\hline $\begin{array}{l}\text { The thickness of exine } \\
\qquad \mu \mathrm{m}\end{array}$ & $\begin{array}{l}3-5 \\
(3.9)\end{array}$ & $\begin{array}{l}4-6 \\
(4.9)\end{array}$ & $\begin{array}{l}3-5 \\
(3.9)\end{array}$ & $\begin{array}{l}5-6 \\
(5.5)\end{array}$ & 4.5 \\
\hline $\begin{array}{c}\text { The spines length } \\
\mu \mathrm{m}\end{array}$ & $\begin{array}{c}2-3 \\
(3)\end{array}$ & $\begin{array}{l}3-4 \\
(3.5)\end{array}$ & $\begin{array}{l}2-4 \\
(2.9)\end{array}$ & $\begin{array}{l}2-4 \\
(3.3)\end{array}$ & 2 \\
\hline $\begin{array}{c}\text { The spines width } \\
\mu \mathrm{m}\end{array}$ & $\begin{array}{c}2-3 \\
(3)\end{array}$ & $\begin{array}{l}3-4 \\
(3.5)\end{array}$ & $\begin{array}{c}2.5-3.5 \\
(3)\end{array}$ & $\begin{array}{l}3-6 \\
(4.9)\end{array}$ & 2 \\
\hline $\begin{array}{c}\text { Distance between spines } \\
\mu \mathrm{m}\end{array}$ & $\begin{array}{c}2-3 \\
(3)\end{array}$ & $\begin{array}{c}2-4 \\
(3)\end{array}$ & $\begin{array}{l}3-4 \\
(3.4)\end{array}$ & $\begin{array}{l}2-4 \\
(2.7)\end{array}$ & $\begin{array}{l}3-4 \\
(3.5)\end{array}$ \\
\hline $\begin{array}{l}\text { Mesocolpium } \\
\mu \mathrm{m}\end{array}$ & $\begin{array}{l}13-17 \\
(14.65)\end{array}$ & $\begin{array}{c}15-20 \\
(16.9) \\
\end{array}$ & $\begin{array}{l}16-19 \\
(17.1)\end{array}$ & $\begin{array}{c}19-21 \\
(20.2)\end{array}$ & - \\
\hline
\end{tabular}




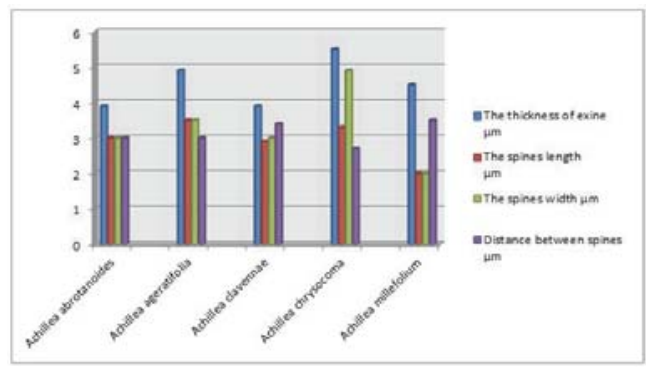

Figure 7. Chart of average dimensions of the palynological features of species Achillea.

Based on the data of the table 2. and fig. 7 observed changes and similarities between the pollen grains of Achillea species. With regard thickness of exine feature, noted that the pollen grains of Achillea chrysocoma, have a thicker exine that pollen grains of Achillea abrotanoides, Achillea ageratifolia, Achillea clavennae and Achillea millefolium. In the length feature of spine noted that the spines appear longer at pollen grains of Achillea ageratifolia, while the wider spines on the basis distinguished in pollen grains of Achillea chrysocoma. The pollen grains of Achillea abrotanoides, Achillea ageratifolia and Achillea millefolium the spines have the same length and width. Distance between spines has not large differences between species, but appears few greater to pollen grains of Achillea millefolium, while mesocolpium is greater to the pollen grains of Achillea chrysocoma.

\section{Conclusions}

From the analysis of palynotaxonomical features of pollen grains of 5 species Achillea show that:

1. The greater pollen grains are at Achillea chrysocoma.

2. The exine appears thicker to the pollen grains of Achillea chrysocoma.

3. The longer spines has Achillea ageratifolia, while the wider spines has Achillea chrysocoma.

4. The pollen grains of Achillea abrotanoides, Achillea ageratifolia and Achillea millefolium have the spines with the same length and width.

5. Distance between spines is slightly larger to pollen grains of Achillea millefolium.

6. Mesocolpium appear greater in the pollen grains of Achillea chrysocoma.

\section{References}

Akyalcin H., Arabaci T., Yildiz B. (2011). Pollen morphology of six Achillea L. sect. Achillea (Asteraceae) species in Turkey Turk J Bot 35: 183-201 doi:10.3906/bot-1005-23.

Alfatemi S.M.H., Rad J.S., Rad M.S. et al. 3. (2015). Chemical composition, antioxidant activity and in vitro antibacterial activity of Achillea wilhelmsii C. Koch essential oil on methicillin-susceptible and methicillin-resistant Staphylococcus aureus spp. Biotech 5: 39. Doi : 10. 1007/s13205-014-0197-x.

Anonymous (1988-2000). Flora e Shqipërisë. Akademia e Shkencave e Shqipërisë (Ed.). Vol. 1, 1988: 1-456: Vol. 2, 1992: 1-446: Vol. 3 , 1991: 1-332: Vol. 4, 2000: 1-502.

Avetisjan B. M. (1950). Uproshennij acetoliznij metod obrabotniki i pilci. - Bot. Zhurnal T. 35, N. 4 : 385 - 386.

Benedec D., Vlase L., Oniga I., Augustin C. Mot., Damian G.,Hanganu D., Duma M., and Dumitrescu S. R. (2013). Polyphenolic Composition, Antioxidant and Antibacterial. Activities for Two Romanian Subspecies of Achillea distans. Waldst. et Kit. ex Willd.. Molecules 2013, 18, 8725-8739; doi:10.3390/molecules18088725.

Demiri M. (1983). Flora Eskursioniste e Shqipërisë. Shtëpia Botuese e Librit Shkollor, Tiranë. 1-986.

Erdtman G. (1943). An Introduction to Pollen Analysis. Waltham, Mass. USA: Chronica Botanica.

Erdtman G. (1952). Pollen Morphology and Plant Taxonomy of Angiosperm,. Almquist and Wiksell, Stockholm. 553.

Erdtman G. (1956). The acetolysis method. A revised description. SvenskBotaniskTidskrift, 54: 561-564.

Issabeagloo E., Taghizadieh M., Abri B.(2012): Antimicrobial effects of yarrow (Achillea millefolium) essential oils against Staphylococcus species. African Journal of Pharmacy and Pharmacology Vol. 6(41), pp. 2895-2899.

Kapidani G. (1996). Bazat e palinologjisë. Spore dhe polene të disa bimëve të sotme të Shqipërisë. Monografi.

Kapidani G. (2005). Fjalori i Terminologjisë Palinologjike. - Sejko, Elbasan: 1-149.

Mazandarani M., Mirdeilami Z. S., and Pessarakli M. (2013). Essential oil composition and antibacterial activity of Achillea millefolium L. from different regions in North east of Iran. Journal of Medicinal Plants Research Vol. 7(16), pp. 1063-1069.

Meo A. A., \& Khan M. A. (2003). Pollen Morphology of Achillea (Compositae-Anthemoideae) Species from Pakistan. Pak J Weed Sci 
$\operatorname{Res} 9$ (3-4): 253-258.

Nemeth E., Bernath J. (2008). Biological activities of yarrow species (Achillea spp.). Curr Pharm Des. 14 (29) : 3151-67.

Punt W., Blackmore S., Nilsson S., Le Thomas A. (1994). The glossary of pollen and spore terminology. LPP Foundation, Utrecht.

Punt W., \& Hoen PP. (2009). Th e Northwest European Pollen Flora, 70: Asteraceae-Asteroideae. Rev Palaeobot and Palyno 157: 22183

Saeidnia S., Gohari AR., Mokhber-Dezfuli N., Kiuchi F.( 2011). A review on phytochemistry and medicinal properties of the genus Achillea. Daru. 19 (3): 173-186.

Sllatkov A.N. (1967). Morfologia pilci i spor sovremnih rasteni V. SSSR Moskva

Smoljaninova L., Gollubkova V. F. (1953). L. A. K. Metodike issledovania pilci. Dok.Ak. Nauk.SSSR T.L XXXVIII. N 3: 125 - 126.

Vitalini S., Madeo M., Tava A., Iriti M., Vallone L., Avato P., Cocuzza C.E., Simonetti P., Argentieri M.P. (2016). Chemical Profile, Antioxidant and Antibacterial Activities of Achillea moschata Wulfen, an Endemic Species from the Alps. Molecules, 201621 , 830.

Wodehouse R.P. (1935). Pollen grains. Their structure, identification and significance in science and medicine. Mc.Graw-Hill, New York \& London: 1-574. 